\title{
Communities of Practice and Their Influence on Improved Academic Performance among Active-Service Military Personnel in Online Education
}

\author{
Eduard Merc \\ Hawai'i Pacific University, Military Campus Programs (MCP) Honolulu, Hawaii, USA \\ emerc@hawaii.edu
}

\begin{abstract}
The purpose of this study is to analyze to what extent communities of practice influence improved academic performance as well as faster adaptability to online classroom settings among U.S. active military students. The study is related to college-level business education courses that were conducted in hybrid online/in-class environment. It provides general insights into how different elements of communities of practice, such as use of collaborative tools, project/time management, knowledge base access, and participation in various student-based organizations at universities are used among military online students to achieve improved overall academic performance in terms of better final grades and course assessment results compared to traditional, non-military students in similar online classrooms.
\end{abstract}

Keywords: Online Education, U.S. Military Students, Communities of Practice, Time Management

\section{Introduction and Literature Review}

E Learning has become a major trend for a variety of colleges and universities that offer academic military programs. Some speak to the increase in online course offerings as well as universities involved in e learning. In fact, there are already more than 50,000 courses taught online and 1,000 universities developing and offering such courses (Carnavale, 2000; National Center for Education Statistics, 1999). E learning has become a very popular medium of studies and expected both in training and formal education environments (Hall, 1997). However, according to Besser and Bonn (1997), some great success stories in the early paradigms of distance learning have come from the field of training and not education. This might be explained by the fact that communicating specific skills and training them to a fixed standard may be easier in a distance-learning environment. Furthermore, the military students might be better prepared to participate in such online curriculum programs based on the collaborative and communication skills acquired during the rigorous military training programs.

Web-based training will grow tremendously in adult and vocational education settings as well as in corporate training sectors (Imel, 1997; Phillips, 1998). Trends in military training often parallel those experienced in their counterparts in corporate and higher education settings. For instance, as with most workplace and college classroom settings, there are increasing demands within the military for learner-centered instruction and the use of technology tools for e-learning, especially those tools that attempt to foster collaboration in the online educational learning (Hara, 2000). The educational technology has become a major driving force of successful adoption of online courses among many respected universities. More and more people take full advantage of online education to pursue their academic endeavors. An increased number of military students are enrolled in some type of online course. The main reason for this development is the overall flexibility, diversity as well as creativity of various educational online tools that assist the military students to become effective and efficient student learners (Small, 1999). Furthermore, many military students are surrounded by formal and informal communities of practice, which can provide direct as well as indirect influence and mentoring for such students to succeed in their academic endeavors (Bandik, 2006).

Community of Practice definition states: "Communities of practice are groups of people who share a concern or a passion for something they do and learn how to do it better as they interact regularly" (Singh, 2003). A recent study in Hawaii-based colleges has found that military students in entry-level business online classes have performed academically better compared to non-military students during 2007-2009 academic periods. The overall grade point average was $20 \%-25 \%$ percent among the military online students than their 
non-military counterparts (Bandik, 2006). This paper attempts to find a link between the profound influence and usefulness of military communities of practice on improved academic performance of military online students. This linkage can later be analyzed further to create and provide more rigorous learning environment for students of various career backgrounds and demographic dispositions.

Not a significant number of studies exist that explicitly examines the learning patterns and academic study effectiveness among military online students. Due to the lack of research data about this subject, this paper attempts to uncover specific influences of communities of practice on the military students, which positively affect the educational engagement and overall academic satisfaction among such students. Some of the questions that need to answered are as follows:

1. Does formation of informal communities of practice help provide military students with skills to succeed in online business classes?

2. Do formal communities of practice play positive role for military students to improve their grade point average results in online classes?

3. What aspects of community of practice positively influence academic performance of military students in online classroom environments?

Therefore, the purpose of this study was to investigate success factors of communities of practice that contribute to improved academic performance among military students in 1000-level online business classes.

\section{Methods}

Participants: The participants of this hybrid online/in-class study were sixty $(n=60)$ undergraduate nonmilitary as well as military students enrolled in an entry-level undergraduate business course at a local notfor-profit university. Twenty-five participants (42\%) were males and thirty-five (58\%) we females. The participants ranged from age 24-41. The convenient sample of participants was entered into the study through their voluntary participation.

Data Collection Instrument: The participants were asked to take one 20-question survey to determine what factors of communities of practice help them succeed in their online classroom environments. The survey was divided into 3 parts reflecting the research attempt to collect information about both formal and informal communities of practice that are prevalent among various U.S. military branches and their active online learners. The first part of the survey collected the students' demographic/personal data. The demographic information was collected to obtain descriptive characteristics for the students. The second section of the survey-evaluated students' involvement in any formal community of practice that operates in the military environment. The third part of the survey evaluated the students' interaction if any with informal communities of practice that relate to study subjects, academic life, and military careers.

The satisfaction form that measured linkage between the military students and their involvement in any type of communities of practice had 9 five point Likert-type items which were adapted from Arbaugh (2000). The scale focused on students' involvement with the community of practice of their choice (formal/informal), their perception of its quality, and their interaction with the community of practice beyond classroom environment. There were positive and negative statements on the scale. The positive items were coded from 5 (strongly agree) to 1 (strongly disagree), and the negative items were coded from 1 (strongly agree) to 5 (strongly disagree) for each statement.

\section{Results}

Some of the highlights of this research study are documented in the following bulleted list:

- Majority of respondents (67\%) belong to formal community of practice organization, such a student business club, university tutoring center, or military rotary club

- Military students were twice as likely enrolled in any type of community of practice then non-military students. 
- Informal communities of practice, such as student-run study groups, online collaboration with other students, and business blogging groups provide additional educational resources for military students to improve their overall grade point average academic performance

- Military student enrollment in both formal and informal communities of practice have contributed to improved cognitive adaption of rigorous online study material, which eventually resulted in improved overall academic performance among military students

- Military students take more opportunities to join university-sponsored communities of practice, such as tutoring services, than non-military students

From the results of the survey, it is evident that social connection among the military online students with various types of formal as well as informal communities of practice provide stimulating effects on students' academic performance, critical analysis of online assignments and assessments, and increased participation in online course forums, such as chat sessions, discussion boards, and synchronous/asynchronous communication tools. Moreover, the survey results also point to an interesting trend of online military students joining free university-offered student services, such as tutoring centers, student club associations, and mentoring initiatives. This trend seems to appear more frequently among the military students than nonmilitary students. This trend might be because the team collaboration and group work/support that is evident in the U.S. military training also greatly affects the academic lives and learning as well as collaboration styles of the military students participating in online curriculum programs.

Discussion: It is evident that the communities of practice play an ever-increasing role between both groups of students, military and non-military learners. However, what is even more evident is the fact that military online students participate more frequently and in more types of communities of practice than non-military students are which often results in lower dropout rates of military students in online classes as well as higher grade point average (GPA) among these students. Furthermore, communities of practice also enable the military students to learn from each other, collaborate on more complex classroom tasks and projects, and eventually develop long-term relationships that can be utilized throughout the academic as well as career life. In other words, the communities of practice act as catalysts for further academic and professional growth among military online students, and thus these communities should be formally supported by colleges and universities that offer military offline/online academic programs.

Furthermore, academic institutions that offer online military programs should adequately provide fertile grounds for creation of informal communities of practice as well as online groups to support academic development and learning styles and growth of military students. Lastly, with the advent of educational technologies and their heavy influence on collaboration and creation of efficient and rigorous communities of practice, the roles of a student as well as an online instructor have been modified. Because the online military students often collaborate in study groups when being deployed and/or reside in the military bases together, they become active learners influenced by a mentor (instructor) that promotes online collaboration, learning, and active facilitation. Thus, we see that the communities of practice among the U.S. military students contribute not only towards an overall student academic success, but also it serves as a catalyst for blending the traditional roles of faculty and learners into energized learning environment characterized by creativity, self-discovery, and improvement of critical thinking skills among online military students.

\section{Conclusion}

The main success factors stemming from the involvement in various communities of practice throughout the academic life of the military online students contribute to the following characteristics that are essential in the overall process of distance education learning:

- Time management tools learned from the collaboration in communities of practice are used prevalently among the military students

- Military students are considered more effective spatial learners than non-military students due to their military career and mandatory technical training that they have received in formal communities of practice. 
- High motivational factors play significant role in the military student's discipline to complete class assignment and obtain satisfactory grades

- Military students seem to cope more effectively with cognitive overload (often prevalent in online classroom environments) due to rigorous military survival and skills training as well as their sense of commitment as a cohesive military team/community of practice

- Military students are actively engaged in well-structured community of practice in various military branches, allowing them to have effective academic, technical, and social support for greater academic performance.

Taken from a different perspective, communities of practice not only act as supporting agents of creative learning among the online military students, but they also seem to influence student personal motivational factors combined with pro-active time/stress managements skills that are necessary in the overall academic success of any student. To sum up, universities across the globe should devote more attention in formal support for various types of both formal and informal communities of practice for military and non-military students, since these 'support groups' provide additional level of academic as well as professional learning that is reflected in improved academic performance and more effective learning environment and personal growth.

Some of the practical recommendations are noted hereafter:

- Stronger focus on communities of practice among academic institutions

- Development and introduction of more robust synchronous collaboration environments in distance education to promote communication, adaptation, and flow of information in today's global world

- Online faculty training to promote creation and adaptation of communities of practice to foster student growth and creativity from multiple sources of learning

Overall, some suggestions for future research in this subject area can include studies regarding the effective collaboration tools used for online curriculum purposes for military distance education programs, the influence of communities of practice on the learning styles and patterns among online military students, and time management techniques used by military students to cope with personal as well as professional pressures of their busy lifestyles.

\section{References}

Arbaugh, J. B. (2000). Virtual classroom characteristics and student satisfaction with Internet-based MBA courses. Journal of management education, 24(1), 32-54.

Bandik, P. (2006). Online Education among Military Cadets. Media Print Kappa Journal, 49(2), 67-75.

Besser, H. \& Bonn, M. (1997). Interactive distance-independent education. Journal of Education for Library and Information Science, 38(1), 35-43.

Carnavale, D. (2000). Survey finds $72 \%$ rise in number of distance learning programs. Chronicle of Higher Education, A57, Washington, DC. http://chronicle.com/free/v46/i18/18a05701.htm

Hall, B. (1997). Web-based training cookbook. New York: Wiley \& Sons.

Hara, N. (2000). Analysis of computer-mediated communication using formal concept analysis as a visualizing methodology. Paper to be presented at the American Educational Research Association, New Orleans, LA.

Imel, S. (1997). Web-based training. Trends and issues alert (Report No. CE075361). Columbus, OH: ERIC Clearinghouse on Adult, Career, and Vocational Education. (ERIC Document Reproduction Service No. ED 414 446)

Phillips, V. (1998). Selecting an online authoring system. Training, 35(4), 53-61.

Singh, H. (2003). Building effective blended learning programs. Educational Technology Journal, 44(1), 5-27.

Small, R. V. (1999). A comparison of the resident and distance learning experience in library and information science graduate education. Journal of Education for Library and Information Science, 40 (1), 27-47. 